\title{
Role of micronutrients in better quality and yield of mango
}

\author{
Pankaj Kumar ${ }^{1 *}$ and Divyangana ${ }^{2}$ \\ ${ }^{1}$ Division of Fruit and Horticultural Technology, PUSA-IARI, New Delhi, India \\ ${ }^{2}$ Department of Horticulture, College of Agriculture, G. B. Pant University of Agriculture and Technology, Pantnagar, Udham \\ Singh Nagar (Uttarakhand) India
}

Email : pankajhtmp@gmail.com

*Author for Correspondence

Research chronicle : Received : 07.11.2018; Accepted : 30.11.2018

KEY WORDS : Role of micronutrients, Better quality, Yield of mango

\begin{abstract}
How to cite this paper : Kumar, Pankaj and Divyangana (2018). Role of micronutrients in better quality and yield of mango. Internat. J. Proc. \& Post Harvest Technol., 9 (2) : 65-69. DOI: 10.15740/HAS/IJPPHT/9.2/ 65-69. Copyright@ 2018: Hind Agri-Horticultural Society.
\end{abstract}

I ndia is bestowed with a wide range of climatic conditions which is most suitable for cultivation of horticultural crops such as fruits, vegetables, flowers etc. The production of horticultural crops has been increased by 30 per cent in last five years. The continuous raise in the production of horticultural crops placed India $2^{\text {nd }}$ most horticultural crop producing country after China. Horticulture has improved economic status of farmers, seasonal availability of fruits throughout the year increased per capita consumption of fruits. Among fruits mango is the major fruits in terms of area and production and regarded as national fruit of India and it has developed its own importance all over the world.

India occupies first place in mango production of the world and accounts for almost half of the global production and area. India being primary and secondary centre of domestication of Mangifera indica, substantial contribution of mango industry in economy, export, livelihood support is well known. Enormous genetic diversity exists in the country. The cultivation of mango in India is as old as 4,000 years as reported by De-Candolle
(1883) and on the basis of writing by subsequent botanist it is 6,000 years (Hill, 1952). Mango is also called "King of fruits" because of it is rich source of nutrient, luscious, aromatic flavour, good amount of dietary fibre and carbohydrates and a delicious taste in which sweetness and acidity delightfully blended. It is one of the most important fruits of India and besides delicious taste, excellent flavour and attractive fragrance, it is rich in vitamins A and C. Mango fruit may be utilized at all stages of its development but generally used at mature stages. The production scenario of different fruits in India indicates that all the fruits occupied 6480 thousand ha area with 92846 thousand MT production and $14.3 \mathrm{MT} /$ ha productivity during 2016-17. The total allocation to the fruits in the country has been increased from 6235 to 6480 thousand ha over the previous year, while the total production of fruits has also been increased from 89512 to 92846 thousand MT among total fruit crops the mango occupied 2263 thousand ha area with 19687 thousand MT production and 8.7MT/ha (National mango database 2017) 